\title{
Public Employment as Fiscal Policy
}

IN A COUNTERCYCLICAL public-employment program, the government attempts to expand employment during a recession and its aftermath by creating additional jobs in the public sector. Congress and the public like such policies, but most economists view them with suspicion. Since considerable experience with public-employment programs has developed over the past five years, the time seems right to evaluate their operation and potential.

Two caveats are in order. The first is that this paper will not address the efficacy of fiscal policy or the desirability of discretionary policy in general. Throughout, expenditures on public employment are assumed to be financed by borrowing. The beneficial effect of this outlay on aggregate demand or national product will be reduced to an uncertain degree by the impact on interest rates. Nonetheless, considerable evidence suggests that, on balance, fiscal policy "works" in the sense that deficit-financed government outlays can increase gross national product and employment. ${ }^{1}$ The

Note: This paper was supported partially by the Institutes of Industrial Relations and Business and Economic Research at the University of California, Berkeley. I am grateful to the discussants and members of the Brookings panel and to George Johnson, Mark Kendall, and Alan E. Fechter for helpful suggestions; to Seymour Brandwein, William Schickler, and Dick Wagner of the Employment and Training Administration for data and advice; and to Leslie Rowland, and the staff of the Income Dynamics Project at Berkeley for research assistance.

1. See Alan S. Blinder and Robert M. Solow, "Analytical Foundations of Fiscal Policy," in Blinder and others, The Economics of Public Finance (Brookings Institution, 1974). 
problem at hand is to identify unique properties of public employment. What can direct job creation accomplish that other, more traditional, discretionary fiscal instruments cannot?

Second, I am concentrating on one type of public-employment program - a countercyclical one-when at least two other models have appeared in the literature. The object of such a program is restoration of normal unemployment rates during a recession and early recovery, and it is designed to be terminated as such rates are approached. In contrast, a "structural" program is the public-sector equivalent of on-the-job training, and is generally advocated as appropriate even for periods of relatively full employment. This kind of program aims to provide skills to special classes of workers and to open civil service to those who have been denied public jobs by prejudice and custom. A job-of-last-resort program-the third model-is simply income maintenance with a work requirement. During the past two years, last-resort jobs have been proposed as backstops to wage-subsidy programs or as an alternative to extended unemployment compensation. ${ }^{2}$

\section{The Case for Countercyclical Public Employment}

The principal argument for a public-employment policy is that outlays on direct job creation move the economy leftward along a more favorable Phillips curve than could be traversed in the same time and with the same dollar outlays spent on alternative fiscal policies. This conclusion is based upon certain presumed properties of public-employment programs and a particular model of the inflation process. Four properties are usually stressed by advocates of the program:

(1) Time shape. Once initiated, public employment can generate a desired level of expenditures more quickly than can other purchase policies.

2. For the first, see Robert I. Lerman, "JOIN: A Jobs and Income Program for American Families," in Public Employment and Wage Subsidies, paper 19 of Studies in Public Welfare, A Volume of Studies Prepared for the Use of the Subcommittee on Fiscal Policy of the Joint Economic Committee, 93:2 (Government Printing Office, 1974). For the second, see Arthur F. Burns, "The Real Issues of Inflation and Unemployment" (speech presented at Blue Key Honor Society Annual Awards Dinner, University of Georgia, Athens, September 19, 1975; processed), pp. 16-17. 
As a corollary, expenditures from a given appropriation will not have as long a "tail" into the future as have, for example, public-works programs. ${ }^{3}$

(2) Job impact. Expenditures on public employment are translated directly into jobs, in contrast with the effects of expenditure (or tax) policies, which occur only as producers respond to increased demand for goods and services.

(3) Pinpointing. Money spent on public employment can be targeted, both geographically and demographically, to an extent not possible with other fiscal or monetary policies. This characteristic makes it possible to achieve a better unemployment-inflation combination or distributional impact than could otherwise be attained.

(4) Deficit. Because a greater proportion of public-employment outlays is recouped in reduced transfers and higher income tax payments, compared with other expenditure policies, such outlays have less impact on the current budget deficit. In theory, the budget deficit can be adjusted to desired levels at any time by other tax or expenditure policies, and this attribute is of little macroeconomic significance. However, political realities may lend importance to the deficit-restraint characteristic.

Given these claimed advantages, the effect of a public-employment program on prices is best understood in the context of a standard model of inflation familiar to readers of Brookings Papers. The model has five components: a wage equation; a price equation; a specification of the relation between demand for output of the private sector and employment; a Keynesian expenditures system that relates demand to income, policy instruments, and other exogenous factors; and a specification of the formation of price expectations.

The wage model is similar to that used by Michael Wachter in his paper in this issue, with a few twists. The rate of change in money wages is assumed to be a function of the unemployment rates of various demographic groups and expected (or recent average) rates of change in some class of prices. The effect of a reduction in the unemployment rate of a segment of the labor force on aggregate wage inflation is assumed to be greater the bigger the group relative to the total labor force, the higher its typical income, the lower its initial unemployment rate relative to "normal"

3. A good example of this phenomenon is provided by the 1962 accelerated public works program. See Nancy H. Teeters, "The 1972 Budget: Where It Stands and Where It Might Go," BPEA, 1:1971, pp. 232-33. 
levels, and the greater the responsiveness of its wage to the labor market. "Normal" unemployment rates aggregate to the full-employment rate of unemployment described by Wachter; for any demographic group, normal rates may differ geographically for structural reasons. The model implies that the effect of reductions in aggregate unemployment on rates of wage change will depend on who is hired.

In the model, rates of change in prices for private output are related to the excess of rates of changes in money wages over rates of productivity increase and the level and rate of change of demand relative to capacity. Both relationships operate with lags; wage inflation in excess of productivity change or an increase in demand for output this quarter will affect inflation rates for several quarters to come.

Employment shifts with demand for output; but it does so with a lag and to a smaller degree, because of inventories, the gradual response of production to demand stimulus, and, during an expansion, the increase in productivity of workers on the job and lengthening of the workweek. Unemployment, in turn, responds less to demand changes than does employment because the labor force tends to vary, in the short run, with fluctuations in total employment.

Finally, if the wage model contains expected rates of price change, it must be closed with a system for determining expectations since the price model determines actual rates of inflation. However expectations might be specified, here it is assumed that public-employment outlays have no more adverse effects on expectations than do other expenditure policies.

In the combined model, the effect of an expansion of aggregate demand on output prices is determined by the level of excess capacity and changes in unit labor costs. As output expands, unemployment diminishes and this, plus any direct effects of demand on prices and price expectations, causes wages to accelerate. Because of the lagging responses of output and employment to an expansion of demand, a substantial reduction in unemployment in the short run requires a much greater stimulus than is necessary for the same reduction in the long run.

In the context of this model the potentially favorable aspects of public employment operate in the following way. The expansion in demand for labor associated with the program circumvents, in the first round of expenditure, the demand term in the price equation and the lag involving orders, sales, production, and employment entailed in ordinary fiscal policy. The concentration of outlays on wages maximizes their initial employment 
effect. The capacity to target allows the job-creating effort to be concentrated on groups and areas where reduction in unemployment puts least pressure on wage inflation. Finally, the reduction of transfers minimizes any problem posed by an overall constraint on the size of the deficit.

Thus, for a given effect on the rate of inflation, proponents argue that, during a recession, public-employment expenditures are associated with gains of output and employment of greater social value than are other fiscal policies. The benefits include the governmental services produced by subsidized jobholders, the enhanced psychological well-being of the otherwise jobless, and possibly a socially desirable redistribution of income.

The heart of the case is that public-employment programs can quickly increase employment of selected workers. The key words here are "quickly," "increase," and "selected." In what follows I consider (a) the actual speed of implementation of public employment; (b) the effect of publicemployment subsidies on the number of jobs filled by local governments; and (c) the process and outcome of the selection of workers for subsidized employment. The paper concludes with an assessment of the congruence of the theory and reality of public-employment policies and the potential for its improvement.

\section{Implementation of Public Employment}

Since 1970 three large-scale public-employment programs have been undertaken. The first was funded through the Emergency Employment Act of 1971 (EEA), the second was initiated by Title II of the Comprehensive Employment and Training Act of 1973 (CETA-II), and the third was the product of the Emergency Jobs and Unemployment Assistance Act of 1974 which amended the original CETA statutes to authorize additional job creation (CETA-VI). Finally, a small number of jobs have been created using money appropriated for training activities under Title I of CETA (CETA-I).

Figure 1 depicts employment in each of these programs for 1971-75. All are still in operation, but the EEA program has dwindled to insignificance. Comparison of the programs should help to identify factors influencing the speed of implementation and the actual intertemporal pattern of expenditures under such programs.

How long does it take to get a public-employment program under way? 


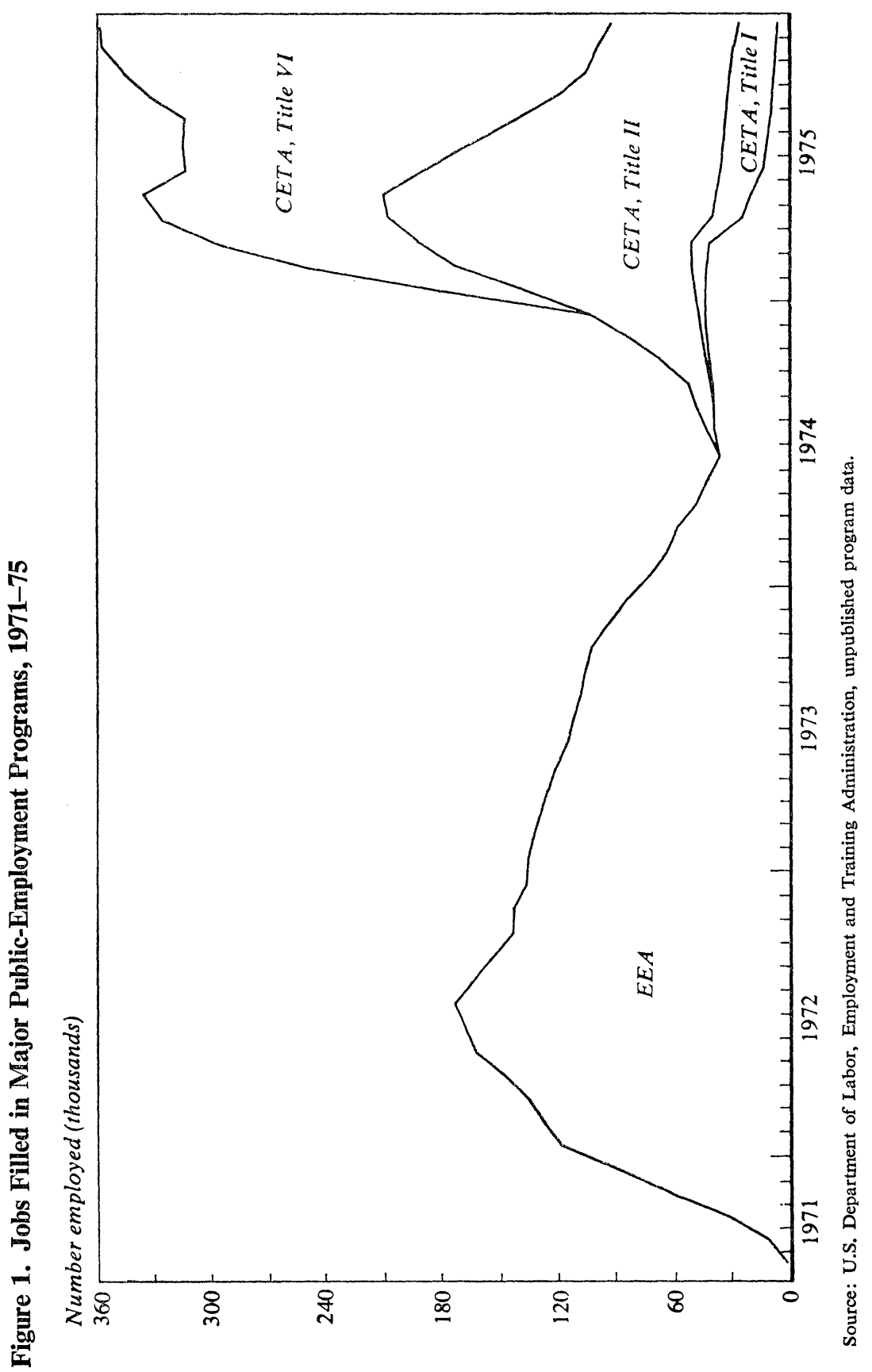


Public employment shares with other fiscal policies the usual triad of recognition, policy, and outside lags. ${ }^{4}$ The recognition lag, the lapse between the point at which a fiscal policy change is needed and the point at which this need is recognized by authorities, is no different for public employment than for other discretionary fiscal policies. The policy lag has two components, legislative and administrative. The legislative component is determined by the time it takes to pass authorizing legislation and seems to be especially short for public-job bills. My impression is that, given executive acquiescence, Congress will pass a public-employment bill at the drop of a hat.

The two delays of significance are the administrative part of the policy lag-the time required to draw up regulations and allocate funds to sponsoring agencies-and the "outside" lag, the time required for jobs to be created and filled. I will argue that, under present procedures, the administrative lag for a program employing 250,000 people now is probably less than a month and the outside lag in job creation is less than two quarters. Because of the small "sample" on which they are based, these conclusions are only tentative.

The length of the administrative lag depends upon the rules included in the legislation to guide allocation of funds. The outside lag depends on the fiscal situation of state and local governments, the restrictions placed on eligible jobs and job candidates, the amount of the subsidy, and the political pressure for rapid job creation. To appraise these elements, it is necessary to review a few of the basic characteristics of these programs.

\section{THE ALLOCATION OF FUNDS}

The EEA and CETA programs transfer federal funds to state and local governments which serve as program agents ("prime sponsors" under CETA) for job creation. Funds appropriated under each program have been allocated among eligible governmental units in accordance with some subset of the following decision rules.

Rule 1 (general unemployment): Allocate funds among states and other eligible areas in proportion to the numbers of persons unemployed. For

4. See Albert Ando and others, "Lags in Fiscal and Monetary Policy," in E. Cary Brown and others, Stabilization Policies (Prentice-Hall, 1963). 
EEA this rule was employed for interstate allocations. ${ }^{5}$ For CETA-VI the initial allocation was made on the basis of relative unemployment to all administrative units including states as program agents for areas not covered by other, lower-level, governments.

Rule 2 (excessive general unemployment): Allocate funds among states and other eligible areas with unemployment in excess of 4.5 percent in proportion to the share of unemployment above 4.5 percent in all such areas. Again, for EEA this rule was applied to interstate allocations; for CETA-VI the collection of prime sponsors served as the basis for distribution of funds.

Rule 3 (concentrated structural unemployment): Allocate funds among states and other eligible jurisdictions on the basis of unemployment in areas of "substantial unemployment" within such jurisdictions. For EEA, an area of substantial unemployment was defined imprecisely as one that had "sufficient size and scope to sustain a public service employment program" and that had an unemployment rate of at least 6 percent for three consecutive months. ${ }^{6}$ For CETA such areas had to consist of contiguous census tracts with a total population in excess of 10,000 and an unemployment rate of 6.5 percent or more for three consecutive months.

Rule 4 (administrative discretion): Allocate funds at the discretion of the secretary (that is, the staff) of the Department of Labor. This rule is typically used for funding experimental projects or for settling disagreements generated by allocations under other procedures.

Rules 1 and 2 presume the existence of disaggregated unemployment data covering the jurisdictions of program agents. For all save the largest standard metropolitan statistical areas, such data are estimated by state em-

5. Programmatic details for EEA and CETA programs are derived from conversations with local CETA administrators and the following sources. For the Emergency Employment Act: Sar A. Levitan and Robert Taggart, "The Emergency Employment Act: An Interim Assessment," in The Emergency Employment Act: An Interim Assessment, Prepared for the Subcommittee on Employment, Manpower, and Poverty of the Senate Committee on Labor and Public Welfare, 92:2 (GPO, 1972); Sar A. Levitan and Robert Taggart, eds., Emergency Employment Act: The PEP Generation (Salt Lake City: Olympus, 1974); and Emergency Employment Act of 1971 (Public Law 92-54; 85 Stat. 146). For the Comprehensive Employment and Training Act, Titles II and VI programs: Federal Register, vol. 39, no. 54 (March 19, 1974), pt. 3; Federal Register, vol. 40, no. 7 (January 10, 1975), pt. 4; Comprehensive Employment and Training Act of 1973 (Public Law 93-203); Emergency Jobs and Unemployment Assistance Act of 1974 (Public Law 93-567).

6. Emergency Employment Act, Public Law 92-54, sec. 6(c). 
ployment services (SES) on the basis of data on unemployment insurance claims adjusted to the decennial census and augmented by other information for uninsured unemployment. These data have not in the past aggregated to national totals derived from the Current Population Survey of the U.S. Bureau of the Census. The Bureau of Labor Statistics is now developing a system for adjustment of state estimates to assure consistency in aggregate with CPS totals. That system will simplify the allocations of funds for job creation in future programs, although the problem of accuracy of local statistics will not be eliminated. ${ }^{7}$

Rule 3 requires unemployment data that are more finely disaggregated than those needed for rules 1 and 2. Areas of substantial unemployment must be pieced together before any allocations can be made, and, unlike the politically defined boundaries used in the other rules, the size and number of such areas will vary from year to year.

Table 1 shows the allocation of funds by rule under the three major employment programs. Whereas for EEA, 60 percent of all funds was allocated on the basis of readily available data on state unemployment rates, for CETA-II no allocation could be made before all areas of substantial unemployment were identified. Completion of the allocation process for CETA-II money took five months. Final allocations were not announced until May $1974 .{ }^{8}$ This potentially costly delay did not, in fact, significantly slow job creation under the program, but only because no appropriation for CETA was made until June 1974.

I conclude that rules similar to those emphasized in EEA and CETA-VI will not contribute to the administrative policy lag in the future, while ones like those in CETA-II would substantially hinder implementation of coun-

7. Data collected for December 1971 in twelve areas selected for "high impact" demonstrations under EEA illustrate the seriousness of this problem. A special census in the designated areas (all densely populated urban counties) using the CPS questionnaire revealed a substantial disparity between the CPS estimates of unemployment and SES estimates made for the same counties for the same month, which were generally lower. Moreover, the pattern of unemployment variation diverged; the simple correlation between the two estimates across areas was only 0.67 . Some of the differences were dramatic: for San Diego, California, the SES unemployment rate was 5.6 percent; the CPS number was 10.5 percent. See National Planning Association, An Evaluation of the Economic Impact Project of the Public Employment Program, Final Report (NPA, 1974), vol. 1, p. 4. Similar results were reported several years ago by Joseph C. Ullman; see "How Accurate are Estimates of State and Local Unemployment?" Industrial and Labor Relations Review, vol. 16 (April 1963), pp. 434-52.

8. U.S. Department of Labor, Employment and Training Administration, unpublished allocation memoranda. 
Table 1. Allocation of Initial Budget Appropriations for Major New Public-Employment Programs, 1971-75, by Type of Employment and Act Proportion of initial appropriation, except as noted

\begin{tabular}{lccc}
\hline & & \multicolumn{2}{c}{$\begin{array}{c}\text { Comprehensive } \\
\text { Employment and } \\
\text { Training } \text { Act }\end{array}$} \\
\cline { 3 - 5 } Type of unemployment & $\begin{array}{c}\text { Emergency } \\
\text { Employment Act }\end{array}$ & Title II & Title VI \\
\hline General unemployment (rule 1) & 0.30 & $\ldots$ & 0.450 \\
Excessive general unemployment (rule 2) & 0.30 & $\ldots$ & 0.225 \\
Concentrated structural unemployment (rule 3) & 0.25 & 0.80 & 0.225 \\
Administrative discretion (rule 4) & 0.15 & 0.20 & 0.100 \\
$\quad$ Total & 1.00 & 1.00 & 1.000 \\
Total initial appropriation & & & \\
$\quad$ (millions of dollars) & 1,000 & $720^{\mathrm{b}}$ & 875 \\
\hline
\end{tabular}

Sources: Sar A. Levitan and Robert Taggart, "The Emergency Employment Act: An Interim Assessment," in The Emergency Employment Act: An Interim Assessment, Prepared for the Subcommittee on Employment, Manpower, and Poverty of the Senate Committee on Labor and Public Welfare, $92: 2$ (Government Printing Office, 1972), pp. 12-15; Federal Register, vol. 39, no. 54 (March 19, 1974), p. 10389; ibid., vol. 40, no. 7 (January 10, 1975), p. 2361.

a. The rule number refers to decision rules for allocating funds, discussed in the text.

b. Includes funds for fiscal years 1974 and 1975, based on continuing resolution.

tercyclical public employment, although they may be appropriate for structural noncyclical programs.

\section{THE NATURE OF JOBS}

Program agents are authorized to create additional jobs in public agencies within their jurisdictions, subject to only loose restrictions. CETA-II jobs are to be provided to "the extent feasible" in occupations for which private and public demand is expanding and are not to be "dead-end" types of employment; they are to fill "public service needs which have not been met and to implement new public services." ${ }^{9}$ For CETA-VI, emphasis on needs was dropped in favor of "employment projects which provide immediate jobs for a maximum number of participants." 10

EEA and CETA funds may not be used to subsidize employees in jobs that otherwise would be filled using local funds, but may be spent to rehire former employees on layoff if a convincing case can be made that otherwise they would remain jobless. For CETA-II, subsidy was initially

9. Federal Register, March 19, 1974, pp. 10391-92.

10. Federal Register, January 10, 1975, p. 2360. 
restricted to entry-level positions to avoid compromising promotional opportunities of regular employees.

The grants provide for total subsidy of wages paid employees in publicservice jobs up to $\$ 10,000$ per employee under CETA and $\$ 12,000$ under EEA. In both cases supplements from local funds are allowed when higher salaries are paid. The grants also make minor provision for administration and training expenses, but none for other overhead expenses.

\section{THE ELIGIBLE POPULATION}

In contrast to the minimal restrictions on the content of the subsidized jobs, both EEA and CETA regulations have substantially restricted the kinds of people eligible for them. With minor exceptions, all programs require that only unemployed persons can be hired for subsidized jobs. The minimum period of prior joblessness was one week initially for EEA, one month for CETA-II, and also one month for CETA-VI except for localities with unemployment rates above 7 percent, where it was cut to fifteen days.

In addition, EEA and CETA regulations specify groups to receive special consideration for employment: veterans, the underemployed, the longterm unemployed, welfare recipients, members of minority groups, and others. The preference for veterans was backed with administrative quotas under EEA, but the other preferences have not been translated into meaningful administrative restrictions.

Under CETA-II, subsidized jobs were restricted to residents of highunemployment areas, in order to assist especially the long-term unemployed and members of households in poverty. The residence restriction imposed by CETA-II did not apply to CETA-VI, and was further reduced by the deepening of the recession, which by early 1975 expanded greatly the number of "areas of substantial unemployment." Moreover, to accelerate employment in that year, prime sponsors were allowed to shift funds among programs, and that shuffle of funds tended to eradicate the fine distinctions among programs with regard to eligible populations.

One program goal under both EEA and CETA has been a high rate of transition of federally funded jobholders into regular civil service or private employment. The transition goal set for EEA was 50 percent, but it was not even approached. Under CETA-II the same goal was established, but local governments were offered an alternative of "placing participants in 
half the vacancies occurring in suitable occupations in [the program agent's] permanent work force which are not filled by promotion from within the agency." 11 The "goal" and the penalties associated with noncompliance generated confusion. Under the Emergency Jobs and Unemployment Act, these transition requirements were pointedly deemphasized for Title VI and, retroactively, for Title II.

\section{THE RECORD}

The major public-employment programs have differed in the specifications for the type of jobs to be provided, the people to be employed, and the ceiling amount of the subsidy. In all respects, CETA-II was more restrictive than EEA. As I have pointed out elsewhere, CETA-II restrictions raised the costs of employment to prime sponsors and the time required to find an eligible jobholder, while lowering the ceiling on wage subsidy and the administrative funds provided for hiring and training. ${ }^{12}$ Hence, it could be expected that jobs would be filled less rapidly in this program than in EEA. For CETA-VI, public employment returned to the less restrictive EEA model in most respects.

The speed of implementation of the programs was also influenced by the changing phases of the business cycle. During the last two quarters of 1971, while EEA jobs were being filled, the unemployment rate remained close to 6 percent. From October 1974 to March 1975, the period of rapid increase in CETA public employment, the rate rose from 6 to $81 / 2$ percent, bringing forth more applicants and greater political pressures for rapid job creation.

On the other hand, the financial condition of state and local governments was much worse during the implementation of CETA in 1974-75 than was the case for EEA in 1971-72. During 1971, the budgets of state and local governments (not including social insurance trust funds) showed declining deficits; in 1972 they moved into surplus on the national income accounts basis. The surplus began to decline in early 1973 and, by the time of implementation of CETA-VI, a substantial deficit had developed. Given the

11. Federal Register, March 19, 1974, p. 10393.

12. See Michael Wiseman, "On Giving a Job: The Implementation and Allocation of Public Service Employment," in Achieving the Goals of the Employment Act of 1946Thirtieth Anniversary Review, vol. 1, Employment, A Study Prepared for the Use of the Subcommittee on Economic Growth of the Joint Economic Committee, 94:1 (GPO, 1975). 
Table 2. Jobs Targeted and Jobs Created in the First Six Quarters under Major Public-Employment Programs, 1971-75

\begin{tabular}{|c|c|c|c|}
\hline \multirow[b]{2}{*}{ Characteristic } & \multirow{2}{*}{$\begin{array}{c}\text { Emergency } \\
\text { Employment } \\
\text { Act }\end{array}$} & \multicolumn{2}{|c|}{$\begin{array}{c}\text { Comprehensive Employment } \\
\text { and Training Act }\end{array}$} \\
\hline & & Title II & Title VI \\
\hline Target number of jobs, year 1 (thousands) & 139 & $90^{\mathrm{b}}$ & 109 \\
\hline \multicolumn{3}{|l|}{ Date of initial allocation } & January 1975 \\
\hline \multicolumn{4}{|l|}{ Jobs at end of quarter (thousands) ${ }^{c}$} \\
\hline 1 & 31.5 & 8.0 & 102.5 \\
\hline 2 & 119.2 & 37.3 & 124.4 \\
\hline 3 & 148.4 & 122.0 & 213.3 \\
\hline 4 & $173.1^{\mathrm{d}}$ & 172.0 & $268.7^{e}$ \\
\hline 5 & 144.9 & 109.1 & $\ldots$ \\
\hline 6 & 135.5 & 69.6 & $\ldots$ \\
\hline Months to target achievement ${ }^{f}$ & 8 & 7 & 3 \\
\hline \multicolumn{4}{|c|}{$\begin{array}{l}\text { Source: U.S. Department of Labor, Employment and Training Administration, unpublished program } \\
\text { data. } \\
\text { a. The target number of jobs is based on the initial congressional appropriation. For CETA-II the initial } \\
\text { allocation is } \$ 370 \text { million in fiscal year } 1974 \text { funds plus } \$ 350 \text { million in continuing-resolution funds for fiscal } \\
\text { year } 1975 \text {. For CETA-VI the initial appropriation of } \$ 875 \text { million was supplemented by } \$ 1,625 \text { million at } \\
\text { the beginning of quarter } 3 \text {. } \\
\text { b. At estimated cost of } \$ 8,000 \text { per job. } \\
\text { c. Quarters are measured relative to month of initial allocation. The month of allocation is month } 1 \text { of } \\
\text { quarter } 1 \text {. } \\
\text { d. Does not include jobs funded for Neighborhood Youth Corps. } \\
\text { e. Preliminary. } \\
\text { f. Rounded to nearest month. }\end{array}$} \\
\hline
\end{tabular}

limited nature of public-employment subsidies, the worse the financial condition of state and local governments, the less may be their ability to utilize the subsidies and particularly to engage in any imaginative concoction of new employment opportunities.

Finally, when EEA was implemented, manpower revenue sharing was new, and hence the necessary network of program administrators had to be established. For subsequent programs, including CETA-VI, the structure was in place and ready to respond to any change in the availability of funds from Washington.

Table 2 records the job creation under each of the three programs measured relative to the date of the initial allocation. These data suggest that the lag in implementation is, to coin a phrase, moderate and variable. The actual pattern is consistent with the hypothesis that the greater restrictiveness of CETA-II did significantly retard implementation, relative to 
EEA and CETA-VI, whatever its merits in targeting jobs more effectively. The relaxation of restrictions and the rapid increase in unemployment apparently combined to accelerate job filling under both CETA programs during the first two quarters of 1975 , despite the adverse financial condition of state and local governments. In the six months, job creation by CETA-II and CETA-VI combined totaled 222,700; by the end of August, 281,200 jobs had been filled.

These totals suggest that a six-month target of 250,000 jobs (or a few more) is reasonable in any renewed effort that might be undertaken in similar circumstances, including (a) an established network of program agents, (b) an ongoing public-employment program, (c) minimal restrictions on eligible employees and employment outcomes, and (d) a high and rapidly increasing unemployment rate. The first condition will be met as long as the country maintains its "revenue sharing" approach to manpower policy. The second was fortuitous and may not be duplicated again, unless some element of the public-employment program is made permanent. The importance of the last two conditions is a matter of conjecture. The rate of job creation by local governments in response to a grant program like that provided by CETA or EEA is a function of local costs and benefits, and any meaningful restriction on eligibility raises costs. The administrative changes in the CETA program at the end of 1974 clearly enhanced the rate of job creation. Similar achievements in the future will require the same flexibility unless incentives are enhanced or methods are devised for lowering costs.

\section{TERMINATION}

Successful implementation of countercyclical public employment requires prompt program termination when prosperity is restored. Given a fixed appropriation, a program that gets started and reaches employment goals quickly will also close promptly, since the sooner the jobs are filled the more rapidly funds are exhausted.

Reality is not quite so simple, for two reasons. First, because jobs are not filled instantly, a reserve of funds develops under fixed appropriations. Unless the program requires that such unspent money be returned to the Treasury, either program employment goals will be exceeded at some point or expenditures will be extended beyond the intended horizon. The former problem arose with EEA by the summer of 1972 and resulted in a freeze 
on replacement of workers who voluntarily quit or obtained unsubsidized jobs, which in turn led to reduction of the transition rate as sponsoring governments tried to maintain their subsidies by keeping existing employees in place..$^{13}$ Under CETA an attempt was made to prevent a similar occurrence; overall public employment has been stabilized at around 300,000 .

Second, terminating people's jobs is always politically difficult. A possible procedure for minimizing the burden on workers and politicians of closure is to rely on natural attrition as subsidized jobholders move into private or regular employment or leave the labor force. As EEA experience demonstrated, however, such a policy creates incentives for local governments to slow transition into regular agency jobs and to do as little as possible to assist jobholders in locating private employment.

The alternative seems to be setting a limit on tenure for temporary employees, backed up by provision for assistance in job search and retraining for jobholders who reach the end of their tenure without finding alternative employment, and by funding to program agents that is independent (or a positive function) of the rate of transition of their temporary jobholders into unsubsidized employment. The fixed-tenure requirement keeps public employees "in the labor market," exerting a restraining influence on wages and reducing the extent of job-search assistance necessary on termination. It also allows a program to be brought to a halt in about a year.

\section{The Problem of Displacement}

Viewed skeptically, the numbers in table 2 show only that when free money is available, local governments will rise to the bait. Once the grants are taken, their effect on output and joblessness will depend on other effects they may have on state and local government budgets. To what extent does money passed to lower-level governments in employment subsidies create incremental jobs? In other words, to what extent are regularly hired state and local employees displaced by workers paid out of federal grants?

Even with a substantial rate of employment displacement, the program may have sizable overall effects on aggregate demand, depending upon how much it raises other local government expenditures or reduces local taxes, rather than merely raising surplus. The displacement of expenditures by

13. Sar A. Levitan and Robert Taggart, "Summary Report I: An Overview," in Levitan and Taggart, eds., Emergency Employment Act: The PEP Generation, p. 35 
state and local governments resulting from grants for public-employment programs will probably be less than the displacement of employment, since both EEA and CETA subsidize only wages paid, and since the production of public services requires nonlabor inputs as well as workers. As a result, funds released by modest displacement are most likely to be used to purchase goods and services.

As the rate of employment displacement increases, however, so does uncertainty about the general impact of the expenditure. For most purposes, analysis of displacement of employees may suffice. If that is large in the short run-say, over a year-countercyclical public employment loses its raison d'être and the size of the multiplier no longer matters. If it is small, funds not spent on wages of incremental employees probably go into government purchases of goods and services. Over the long run, displacement seems unavoidable as successive budgets are adopted and both program agents and the administering bureaucracy lose perspective on what employment would have been in the absence of such funds. In itself, the extent of long-run displacement has no relevance to the effectiveness of the short-run countercyclical program. At most, the path of adjustment of employment to the long-run level may provide some information about the employment effects over the time horizon that is critical for countercyclical purposes.

Only two estimates of short-run employment displacement by public employment grants are available. ${ }^{14}$ The first, made by George E. Johnson and James $\mathrm{D}$. Tomola, is based on time-series data on aggregate state and local employment $;^{15}$ the second was prepared using microgovernmental data by

14. In addition, one long-run evaluation has been made by Alan Fechter. He obtained a measure of displacement by first estimating the impact of public-employment grants on overall expenditures and then translating the expenditure effects into jobs created. (That reverses my preferred approach of first evaluating the net impact of a publicemployment program on jobs filled, then calculating the amount of funds released by displacement, and finally speculating on the disposition of these funds.) In his first step, Fechter relied on long-run estimates of the impact of grants of various types on local government expenditures and therefore his estimate of the impact of public-employment grants on jobs filled by such governments are really long-run estimates. It is likely that the short-run effects of public-employment grants on the wage bill and total expenditures differ from those of the categorical and lump-sum grants on which his estimates are based. See Alan E. Fechter, "Public Employment Programs: An Evaluative Study," in paper 19 of Studies in Public Welfare.

15. George E. Johnson and James D. Tomola, "The Efficacy of Public Service Employment Programs," Technical Analysis Paper 17A (U.S. Department of Labor, Office of the Assistant Secretary for Policy, Evaluation, and Research, 1975; processed). The estimate was originally circulated in a working paper for the Office of Policy, Evaluation, 
the National Planning Association. ${ }^{16}$ The two yield substantially different estimates of short-run displacement; both seem to be seriously flawed.

\section{AN AGGREGATE TIME-SERIES ESTIMATE}

To estimate the rate of displacement of locally funded jobs by those subsidized through EEA, Johnson and Tomola regressed aggregate nonsubsidized employment not associated with education in state and local government on real personal income minus federal taxes (plus state and local indirect business taxes) lagged four quarters, EEA-subsidized jobs, and nonsubsidized jobs lagged one quarter, all expressed per capita, using quarterly data for 1956:1 to 1973:2. The estimated equation includes seasonal dummies and a linear time trend; it fits the data well, and the publicemployment term in the regression has a statistically significant negative coefficient. The results indicate that the immediate impact of creating one hundred federally subsidized jobs is a reduction in nonsubsidized state and local employment of twenty-nine jobs, leaving a net increment to state and local government employment of seventy-one. After eight quarters, however, that net increment has eroded to only about thirty-three, the longrun effect.

Five problems make it hard to accept the Johnson-Tomola estimate. First, wages do not enter the model, which, in effect, is a demand equation without a price variable. The time trend is meant to "[approximate] changes in relative prices and in community preferences." 17 But, in fact, relative prices did not change linearly over the seventy quarters of the data.

As has been pointed out by others, wages in the public sector began rising rapidly in absolute terms and relative to earnings in the private sector in the late 1960s. ${ }^{18}$ Data from the Census of Governments show a 5 percent jump in the average real payroll cost of fulltime equivalent state and local government employees in 1972 alone. ${ }^{19}$ This jump is closely correlated with

and Research in the Department of Labor; it subsequently was cited in the 1975 Economic Report of the President, pp. 124-25, the 1975 Manpower Report of the President, p. 46, and in Congressional Budget Office, Temporary Measures to Stimulate Employment: An Evaluation of Some Alternatives (CBO, 1975), p. 38. My comments in this section cover only a fraction of this interesting paper.

16. National Planning Association, Evaluation of the Economic Impact Project. The displacement estimates are described in vol. 3, app. M.

17. Johnson and Tomola, "Efficacy of Public Service Employment Programs," p. 9.

18. Charles L. Schultze and others, Setting National Priorities: The 1973 Budget (Brookings Institution, 1972), p. 297.

19. U.S. Bureau of the Census, Public Employment in 1974 (GPO, 1975), p. 8. 
the advent of EEA. The public-employment term in the Johnson-Tomola regression takes on a nonzero value only in the last eight of the seventy observations. This coincidence of public-employment programs and increases in wage cost could exaggerate the extent of displacement, especially since militance on the part of public employees and wage gains may have been greatest in large cities, the site of much EEA employment.

Second, the model is ill-equipped to deal with short-run adjustment of employment to cyclical variation of revenue in the public sector. In the Johnson-Tomola analysis, demand for public employees is derived from the demand by citizens for public services. This, in turn, is assumed to be a function of personal income minus federal income taxes. State and local indirect business taxes are added to adjusted personal income presumably on the assumption that such taxes are shifted forward. As indicated above, the income variable enters with a four-quarter lag, and no allowance is made for the effects of short-term, recession-induced reductions in tax yields or price changes on state and local government employment. If used to simulate the impact of, say, a sudden fall in personal income on state and local employment, the model would predict no effect at all for four quarters.

If, in reality, state and local governments slow the hiring of new employees or replacement of old ones more promptly as revenues falter during a recession, the result will show up in the Johnson-Tomola model as a negative residual..$^{20}$ If a public-employment program is initiated at the time such adjustments are under way, the subsidized employment term in the model will be correlated with the residual and its coefficient will be biased downward, perhaps exaggerating the extent of displacement.

Third, Johnson and Tomola assume that unsubsidized employment of state and local governments is adjusted to desired levels at the same rate in response to introduction of subsidized employees as in response to, for example, a change in income. The impact is distributed over a long period with proportionately the greatest share of adjustment occurring in the first quarter in which subsidized employees are introduced. The functional form adopted permits no other conclusion. Yet both federal representatives and

20. The overestimate of employment will be reduced somewhat over time by the presence of the term for employment in the preceding quarter. But in a "partial adjustment" model of this type, the coefficient of the lagged employment term has a specific interpretation that affects the estimated long-run displacement effects of subsidized employment. Any bias induced in the coefficient of lagged employment by its correlation with the disturbance term biases also the estimate of displacement. 
local public employees are most diligent about avoiding displacement during the first quarter of implementation; most on-site observers argue that displacement creeps in later-after the "heat" is off. ${ }^{21}$ This time shape of displacement is critical for the use of subsidized employment as countercyclical policy. Hence, the particular constraint on the functional form they use seems inappropriate.

Fourth, more than one type of displacement occurred at the time of implementation of EEA. The Nixon administration chose to utilize EEA funds for summer jobs for youth that in preceding years had been funded through other programs. ${ }^{22}$ The number of such jobs was substantial, approximately 100,000 in June 1973 . The displacement of summer youth jobs by EEA summer youth employment was 100 percent, and the inclusion of the latter in the data used for analysis of displacement by local government probably biases upward the estimated degree of displacement. ${ }^{23}$

Finally, since data on employment-program jobholders are not reliably disaggregated either by job type or by type of employer, it is impossible to separate EEA (or, for that matter, CETA) employment in educational capacities from that in other governmental functions. Johnson and Tomola use a rough estimate that 19 percent of all EEA jobs were in educationrelated activities. This cumulative figure probably disguises important variation over time and may differ from the composition at any one time because of differences in turnover between employees in subsidized jobs in education and those located elsewhere in state and local government. Its use creates "errors in variables" problems on both the left- and right-hand sides of the Johnson-Tomola equation.

Aside from the transfer of summer youth employment to a separate title of CETA, these problems have not been alleviated with later public-employment programs. If anything, the prospect of gleaning a reliable displacement estimate from time-series data is now less promising because public employment is spread over four programs instead of one, and each may have a different displacement effect. I have experimented with a model similar to that employed by Johnson and Tomola; it differs in that it includes a wage term, adjusts employment figures for summer jobs, covers employment in both education and other governmental activities, intro-

21. Later in this section I comment on these reports.

22. Levitan and Taggart, "An Overview," p. 17.

23. Summer employment of youth is handled under a separate title of CETA. Summer EEA jobs are not included in figure 1. 
duces a more elaborate lag structure for income, incorporates a different seasonal-adjustment procedure, and extends the sample period to 1975 . The results indicate that inclusion of a wage term does reduce the displacement estimate but that slight modifications in the functional form and time period covered can move estimated short-run displacement rates from virtually zero to as high as 80 percent.

\section{AN ESTIMATE USING CROSS-SECTION DATA FOR CITIES}

Of the funds appropriated for the Emergency Employment Act, $\$ 65$ million was devoted to a "high-impact demonstration project," in which program agents in California, Illinois, New Jersey, New York, and South Carolina were given unusually large grants for public employment to test the impact of such procedures on local labor markets. Whereas the slots funded by the EEA programs were sufficient to hire between 1 and 1.5 percent of the unemployed nationwide, those allocated to the demonstration areas were numerous enough to employ about 7.7 percent of the jobless in all those areas as of December 1971. ${ }^{24}$

The National Planning Association (NPA), which performed a wideranging evaluation of the high-impact experiment, estimated that, for every one hundred jobs created in the high-impact demonstration area during the fall of 1971, net employment by the participating governments was increased by only fifty-four slots as of the following October. ${ }^{25}$ This is the only displacement estimate available that is based on cross-section data for individual governments.

The NPA's procedure for deriving this result is straightforward. ${ }^{26}$ To obtain a control for evaluation of displacement, every government in the demonstration areas was matched with another unit in the same state. Elaborate efforts were made to assure that the comparison government was of the same type, differed in total employment from the demonstration unit by no more than 5 percent, and had employees distributed across functions in roughly similar proportions. The average difference in employment between experimental and control groups was calculated using data from the Census of Governments for October 1967, 1969, 1970, and 1971. This

24. National Planning Association, Evaluation of the Economic Impact Project, vol. 1, p. 6.

25. Ibid., p. 112.

26. Ibid., vol. 3, app. M. The description that follows is taken from this appendix. 
average was used to predict the expected difference for October 1972; if the difference showed a trend, this trend was projected for the 1972 forecast.

Employment by the "control" governments plus the estimated difference between control and experimental governments was used to predict employment in the experimental sites for October 1972. The difference between actual and predicted employment could then be calculated and divided by EEA employment in the experimental sites for an estimate of the proportion of subsidized jobs that were actual increments to local government employment-the "creation rate."

The results of the experiment were flawed by three things: (1) the data for the control group were contaminated by the presence in the employment figures of an unknown number of jobholders hired with EEA funds; (2) the NPA miscalculated the displacement rate; and (3) no adjustment was made for the actual pattern of implementation.

The importance of these problems can be illustrated by examining the ideal formula. I concentrate for illustration on data for all governments combined rather than on any disaggregation. Let $E H^{*}$ represent the predicted average employment (ignoring public employment) in the high-impact governments; $E C$ is average employment in the control governments; $E H$ is actual average employment for high-impact-area governments; $d^{*}$ is the predicted difference between employment in the high-impact and the control governments; $\alpha$ is the creation rate over the horizon of the NPA experiment ( $1-\alpha$ is the displacement rate); and $P H$ is public employment in the high-impact sites, all measured as of October 1972. Then,

$$
E H^{*}=E C+d^{*},
$$

and

$$
\alpha=\frac{E H-E C-d^{*}}{P H}
$$

The numerator represents the net "unexpected" extra jobs and the denominator is the gross contribution of public employment.

For the combined sample, $d^{*}$ was estimated to be $35, E H$ averaged 683, $E C$ was 631 , and $P H$ averaged 34 for the high-impact-area governments. ${ }^{27}$ These numbers substituted in equation 1 suggest a creation rate of 0.5 , which reflects substantial displacement.

27. Ibid., p. M-11. 
Now the problems: The last observation for estimation of $d^{*}$, that for October 1971, already involved some EEA jobs. The NPA reports that 7 percent of jobholders in demonstration areas were on the job in October. ${ }^{28}$ This would be, on average, about two and one-half people per demonstration-area government. Presumably, some EEA jobs were also filled among the control group at this time, but no data were collected for this group. While EEA employment was ultimately above average in the demonstration projects, jobs were filled less rapidly there. Therefore, the effect of this contamination on the observed difference in October 1971 is uncertain. I shall assume that the effects cancel out and the estimated $d^{*}$ remains 35 . The NPA's adjustment will be shown later.

Although the size and significance of EEA employment in October 1971 is a matter of doubt, plainly there was substantial EEA employment in the control group by October 1972. The NPA estimates the extent of such employment to be 1.5 percent of all jobs filled in the control group on the basis of national data on EEA hires as a proportion of all state and local employees. To account for this, expression 1 must be modified, and the adjustment must incorporate an assumption about the extent of displacement in the control group. Assuming the same adjustment is appropriate for both control and experimental groups, expression 1 becomes

$$
\alpha=\frac{E H-\left(E C+d^{*}-\alpha \beta E C\right)}{P H},
$$

where $\beta$ is the proportion of average employment in the control areas that is federally subsidized. Solving for $\alpha$,

$$
\alpha=\frac{E H-E C-d^{*}}{P H-\beta E C} .
$$

Adjustment for control contamination in October 1972 (assuming $\beta=$ 0.015 ) raises the estimate of the creation rate to 0.69 . Inexplicably, the NPA adjusted equation 1 for contamination by multiplying the numerator by 0.985 , the proportion of employees assumed not to be subsidized by EEA in the control group, and subtracting half the number of EEA employees in place in the demonstration areas in October 1971. The result is a higher displacement rate, for which a standard error of 0.04 is claimed. ${ }^{29}$

As formula 3 indicates, these estimates are exceedingly sensitive to the assumption made about $\beta$, a parameter for which no data were collected.

28. Ibid., p. M-15.

29. Ibid, vol. 1, p. 112. 
If it is 0.02 instead of 0.015 , the creation estimate rises to 0.80 ; if $\beta$ is 0.01 , on the other hand, the estimate of $\alpha$ becomes 0.61 .

The result rests precariously on the assumption that the same displacement rate applied to both the control and the high-impact cities. Despite the NPA's assertion that the rate will vary with time, it is not adjusted for the time pattern of job creation in the demonstration or control sites. It implies that marginal and average displacement rates are equal (as do the time-series estimates in the preceding section). Perhaps, for smaller numbers of subsidized jobs, the displacement effects would have been greater. The governments in these "demonstration sites" knew their public-employment efforts would be evaluated by an independent consulting firm; thus, the "Hawthorne effect" may have restrained displacement. These factors, plus the imprecise character of some of the underlying numbers, must lead to substantial reservations about the NPA estimate. ${ }^{30}$

\section{ON-SITE EVALUATION}

A third source of information on displacement is provided by reports of on-site observers of program implementation. Levitan and Taggart, for example, conclude from such evaluations that "at the outset, the level of PEP jobs represented net additions to the total number of public employment opportunities." ${ }^{31}$ These estimates must also be viewed with reservations. It is difficult for an outsider to gauge displacement by looking at the first jobs in local government that subsidized workers do. Such jobs can change quickly over time, and the actual employment effect of subsidized jobs depends not only on what new workers do but also on what is happening simultaneously to the duration of vacancies in unsubsidized slots. Possibly the process of adjustment to subsidized employees "displaces" employment even while each subsidized employee begins work on a job that all observers might agree is "new."

Most state and local governments have employment screening procedures that are adapted to the normal rate of turnover of their labor force.

30. The NPA provides estimates of the creation rate also by type and size of governmental unit. The estimates range from 1.11 for cities and towns to 0.17 for special districts, and are subject to the same problems encountered with the aggregate figures. However, they do suggest possible behavioral differences that could lead to a better understanding of the displacement process if it is systematically studied. See ibid., vol. 3, p. M-16.

31. Levitan and Taggart, “An Overview," p. 17. 
The evidence that is available on turnover in local government suggests that this rate is low compared to experience in the private sector. ${ }^{32}$ While EEA and CETA jobs may not represent a significant increment to total state and local employment, the number is substantial compared to the rate of turnover over the period in which they were filled. When the employment effort of local government is directed toward applicants for subsidized jobs, the duration of unsubsidized vacancies may rise, offsetting part of the employment effect of the subsidized employment. Once subsidized jobholders are in place, these governments can reorient their employment facilities toward unsubsidized vacancies. In the absence of other effects, this might produce a gradual reduction in the displacement effect over time. However, the passage of time also permits reallocation of duties so that subsidized employees initially employed on "new" jobs come increasingly to perform old ones, thereby translating a temporary displacement into a permanent one.

The displacement generated by this "digestion" process cannot be detected by looking at the nature of the jobs initially filled by subsidized employees. What must be inspected are changes in the vacancy rate for unsubsidized jobs at the time of implementation of subsidized employment and the tasks of subsidized employees in quarters subsequent to initial hire. Any increase in the duration of vacancies in unsubsidized employment reduces the effect of the countercyclical jobs program. Such changes are difficult to observe on site, but may be reflected in aggregate employment statistics.

\section{WEIGHING THE EVIDENCE}

I can offer no definitive estimates of the displacement effect. The estimates derived by Johnson and Tomola from time-series data appear on balance to be biased toward exaggeration of displacement. The impressions provided by on-site observation are likely to err in the opposite direction, because they do not encompass any indirect displacement effects operating through hiring procedures and duration of vacancies of unsubsidized slots.

All told, the best available number is that based on the NPA study after adjustment: it suggests that displacement over approximately three quarters is no higher than 40 percent. The "displaced" funds will presumably have

32. Frank Levy and I estimate that the annual turnover rate in low-skill jobs in the city government of Oakland, California, may be less than 10 percent. See Frank Levy and Michael Wiseman, "An Expanded Public-Service Employment Program: Some Demand and Supply Considerations," Public Pollcy, vol. 23 (Winter 1975), p. 121. 
the same impact on employment as would added funds for general revenue sharing; the bulk of the funds, which are not displaced, are likely to exert a substantially greater impact on employment than that provided by revenue sharing.

The rate of displacement is probably lower under CETA than under EEA. In the more recent program, procedures for policing maintenance of effort are somewhat more rigorous, and administrators seem more aware of the potential for displacement and more involved in policing primesponsor activity now than was the case in 1971. Also, since CETA job creation occurred under far more adverse general economic conditions than were true for EEA, displacement related to "digestion" was probably less of a problem; job turnover in local government may have been lower and the number of vacancies arising in unsubsidized jobs may have been smaller. On the other hand, the financial condition of state and local governments was considerably worse during the first half of 1975 than during the fall of 1971. While this situation may have assured that little or no CETA money made its way into idle surplus, it also may have exacerbated tendencies toward displacement as local governments sought to divert funds for meeting nonwage as well as wage expenses.

\section{Targeting}

Under existing program organization, the number of subsidized slots for temporary public-service employment always falls short of the demand for them by local governments and individual applicants. This imbalance permits the use of special allocation criteria to yield the greatest social value of the program. In this section, the actual geographic and demographic allocation of jobs will be described.

Given the number of jobs to be filled, the social value of public employment is greater (a) the greater the output from such jobs, (b) the less the effect of such employment on wages, and (c) the greater the benefits to family welfare. Measurement of the output of subsidized public employees is subject to all the usual difficulties encountered in evaluating government product. The impression of outside observers is that typical jobholders do work similar in content and quality to that performed by other, regular, public employees; but beyond this little can be said. ${ }^{33}$ Program agents can

33. Levitan and Taggart, "An Overview," pp. 20-25. 
be expected to take care of output maximization, since this is likely to be their most important objective. The control problem is to devise regulations or incentives so that outcomes will also reflect the importance of the second and third objectives.

The appropriate standard for evaluation of the inflationary effect of public employment is not clear. Not much is known about the nature of the short-run response of wages to unemployment within areas of the national labor market or for specific demographic subgroups. My analysis is based on three assumptions, which are consistent with the model sketched at the beginning of the paper. The first is that categories like "workers in Seattle" and "workers in Houston" or "men" and "women" can, to some extent, be viewed as noncompeting groups in the labor market. Second, for such groups (or areas), wages respond to the category's employment conditions in a manner similar to the aggregate (convex) Phillips relation between rates of wage change and unemployment. Moreover, for a variety of structural reasons, the "normal" unemployment rates that keep labor markets in balance will differ among categories. Third, all other things equal for each category, the slope of its sectoral Phillips curve at a given current unemployment rate will be flatter the lower the normal unemployment rate of that sector. To put it another way, a large above-normal component of unemployment is one indicator of labor-market slack, associated with less marginal wage pressure from incremental employment.

Two conclusions follow from these assumptions: (1) In the absence of other considerations, the inflation-minimizing distribution of public employment across groups will involve a ratio of jobs created to labor force that is an increasing function of both their normal unemployment rates and their recession-induced, or above-normal, unemployment rates. (2) So long as the "need" for jobs is related to both the level and above-normal component of unemployment rates, the allocation of jobs on the basis of "need" will not necessarily conflict with the anti-inflationary objective. I shall now apply this analysis, as well as other relevant considerations, in evaluating CETA job allocation across geographic labor markets and demographic groups.

\section{THE DISTRIBUTION ACROSS LOCAL LABOR MARKETS}

How much geographic variation in unemployment rates during recession is actually observed? In table $3 \mathrm{I}$ have listed the weighted mean absolute 
Table 3. Dispersion of Unemployment Rates, Nineteen Major Standard Metropolitan Statistical Areas, 1968-73 and 1975

\begin{tabular}{ccc}
\hline Year & Dispersion index & $\begin{array}{l}\text { National unem- } \\
\text { ployment rate }\end{array}$ \\
\hline 1968 & 0.66 & 3.6 \\
1969 & 0.64 & 3.5 \\
1970 & 1.09 & 4.9 \\
1971 & 1.40 & 5.9 \\
1972 & 1.07 & 5.6 \\
1973 & 1.03 & 4.9 \\
1975 & 1.82 & 8.5 \\
\hline
\end{tabular}

Sources: Manpower Report of the President, March 1972, and ibid., April 1974, tables A-1 and D-13 in each; and unpublished 1975 data furnished by the U.S. Bureau of Labor Statistics.

a. For the areas covered, see text note 34 .

b. Dispersion index:

$$
D=\frac{\sum_{i=1}^{n} L F_{i}\left|U_{i}-U\right|}{\sum_{i=1}^{n} L F_{i}} .
$$

where $U_{i}$ and $L F_{i}$ are unemployment rates and labor force, respectively, in SMSA $i$, and

$$
U=\frac{\sum_{i=1}^{n} L F_{i} U_{i}}{\sum_{i=1}^{n} L F_{i}} .
$$

difference of SMSA unemployment rates from the overall average for nineteen major SMSAs for the period of $1968-73$ and for $1975 .{ }^{34}$ As is apparent, the dispersion of unemployment across SMSAs increases with aggregate unemployment. ${ }^{35}$

34. The SMSAs are San Francisco-Oakland, Buffalo, Boston, Los Angeles-Long Beach, Detroit, New York, Pittsburgh, Philadelphia, St. Louis, Newark, Cincinnati, Minneapolis-St. Paul, Houston, Washington, Chicago, Cleveland, Milwaukee, Baltimore, and Dallas (which includes Fort Worth in 1975). Figures for 1968-72 are based on 1960 census boundary definitions; those for 1973 and 1975 reflect definitions current in those years. As a result, the numbers are not strictly comparable, but biases are likely to be very small. The measure of dispersion used here was first proposed by Robert Aaron Gordon; see The Goal of Full Employment (Wiley, 1967), p. 93. The 1975 unemployment rates have not been adjusted for CETA jobs. If these jobs reduced unemployment, the results that follow indicate that dispersion in 1975 would have been greater in the absence of the program.

35. For similar results, see Andrew M. Sum and Thomas P. Rush, "The Geographic Structure of Unemployment Rates," Monthly Labor Review, vol. 98 (March 1975), pp. 3-9. Note the interesting regularity in table 3 in the relative constancy of the 1:5 ratio of the dispersion index to national unemployment rates. 
The argument for targeting subsidized public employment presumes that such expenditures can partially offset this unevenness in impact. Given the program's modest size, such an effect is unlikely. Rather, I have attempted to determine whether existing allocation rules in fact produced a positive relation between unemployment rates across SMSAs and the ratio of public-service jobs to the labor force for each area. For this analysis, I prepared a breakdown of public-employment jobs coincident with the SMSA data by sorting employment reports of CETA prime sponsors by SMSA and then counting across prime sponsors to arrive at figures for subsidized employment in each metropolitan area.

Two simple tests were conducted with these data. The first demonstrated that the geographical distribution of CETA jobs (measured relative to the labor force) has been positively associated with differentials in unemployment rates. Equation 4 reports the results of a regression of the ratio of subsidized jobs filled in each of twenty-eight SMSAs in June 1975 to its average monthly labor force for that year (the CETA rate) on its average adjusted unemployment rate for $1975, U_{75}^{*}$. The adjusted rate is formed by adding to the conventional unemployment rate the ratio of CETA jobs to the average monthly labor force. ${ }^{36}$ In making the latter adjustment, I have assumed that every CETA job filled by June was associated with a reduction of one in average annual unemployment in that SMSA. ${ }^{37}$ The coefficient of the adjusted unemployment rate is positive and statistically significant; the negative intercept indicates that the marginal increase in CETA jobs associated with a change in unemployment rates is somewhat greater than the average CETA rate for any rate of unemployment. CETA employment was, to a modest extent, concentrated in SMSAs with high unemployment.

$$
\begin{gathered}
\text { CETA rate }=-0.0018+0.0470 U_{75}^{*} . \\
(-1.95) \quad(4.93) \\
R^{2}=0.47 ; \text { standard error }=0.0012 .
\end{gathered}
$$

Here and in the following equations, the numbers in parentheses are $t$-statistics.

36. In addition to the nineteen SMSAs cited in note 34, the sample includes NassauSuffolk (which was separated from the New York SMSA in November 1972), Miami, Indianapolis, Kansas City, Denver-Boulder, Riverside-San Bernardino-Ontario, San Diego, San Jose, and Seattle-Everett. Recent significant boundary changes prevented inclusion of Atlanta, the remaining major SMSA for which unemployment data from the CPS are available.

37. This assumption is probably generous, given the results of the preceding section as well as the possibility of induced participation effects. But the results of importance here are not sensitive to reasonable alternative specifications. 
The second test gauges the extent to which the allocation of CETA jobs was influenced by the increment in unemployment rates associated with the current recession. As is well known, various structural factors generate substantial and consistent differentials in unemployment rates across metropolitan areas. ${ }^{38}$ To measure the extent to which actual allocation of public-employment jobs responded to the recession-induced component of unemployment, a separate regression was calculated for twenty-six SMSAs for which data on the unemployment rate were available for 1972-73 as well as 1975. I assume that the average unemployment rate for the earlier period $\left(\bar{U}_{72-73}\right)$ is a reasonable proxy for "normal" unemployment for each SMSA. It is included along with a measure of recession-induced unemployment (the difference between the adjusted unemployment rate in 1975, $U_{75}^{*}$, and this average) as an independent variable in a regression determining the CETA rate, defined as for the previous test. The results are reported in equation $5 .{ }^{39}$

$$
\begin{aligned}
& \text { CETA rate }=-0.0023+0.0732 \bar{U}_{72-73}+0.0199\left(U_{75}^{*}-\bar{U}_{72-73}\right) . \\
& (-2.55) \quad(5.46) \\
& R^{2}=0.59 \text {; standard error }=0.001 \text {. }
\end{aligned}
$$

Equation 5 indicates that CETA job allocation across SMSAs was positively associated with cyclical unemployment differentials, but the allocation is principally and most reliably associated with differences in past average unemployment.

The correlation between changes in unemployment rates (adjusted for CETA) and the 1972-73 average is almost zero- + 0.04 . Past unemployment differentials did not provide a good clue to the increase in SMSA unemployment associated with the current recession. Both CETA-II and CETA-VI allocations were based on levels of joblessness during threemonth periods in 1974. These results suggest that while the substantial correlation between levels of unemployment rates across years assured that cities with high rates in 1975 would get proportionately more jobs, the allocation mechanism does not concentrate jobs in areas disproportionately subjected to cyclical joblessness. If estimates of local Phillips relations available in the future indicate that the anti-inflationary objective can be enhanced by making job creation more sensitive to such cyclical differentials, the job-allocation procedures used for CETA must be revamped.

38. See Robert E. Hall, "Why Is the Unemployment Rate So High at Full Employment?" BPEA, 3:1970, pp. 375-84.

39. Since data on program-agent employment were not available for EEA, the unemployment rates for 1972-73 used in equation 5 are not adjusted for EEA jobs. 
Since the coefficient of the cyclical differential term in equation 5 is so small, my subjective assessment is that marginal efforts in this direction would be quite certain to change allocation; and I would expect the change to improve the wage effect of public-employment programs. ${ }^{40}$

\section{DEMOGRAPHIC DISTRIBUTION}

The standard for consideration of labor-market effects of allocation of jobs across demographic categories of workers will be similar to that used above for evaluation of the geographic distribution. In the analysis of demographic distribution, the differences among EEA, CETA-II, and CETA-VI programs can be used to identify the response of public employers to variations in program characteristics.

Within the broad demographic categories, distinguishing between "lowskill" and "high-skill" groups is difficult, although the Congressional Budget Office and others have argued that concentration of public employment among low-skilled workers would minimize the impact of public employment on prices. ${ }^{41}$ Other things equal, including proportionate changes in unemployment rates, it is not clear why this should be true. Since markets for low-skilled labor may be among the most competitive of all labor markets, wages there will presumably react most promptly to easing or tightening of labor markets. However, to the extent that low-skilled workers experience proportionately more joblessness than do higher-skilled groups, the criteria advanced earlier indicate that they should benefit more from employment programs in any event.

The effect of subsidized public employment on wages in the private sector cannot be assessed only by its impact on unemployment rates. If workers in public jobs continue active search for other jobs because their wages are low or their jobs are certain to be temporary, they may exert as much downward pressure on wages as they would if they were jobless. The tradeoff between impact on wage inflation and impact on family welfare poses a paradox: To minimize inflationary effects, the best candidates for $\$ 8,000$

40. It is possible that allocations under the CETA-VI programs were more closely associated with cyclical changes in unemployment rates than is apparent from the analysis of the combined effect of CETA-II and CETA-VI. But the permitted shifting of funds between programs during the spring of 1975 makes separate analysis of the allocation of CETA-VI money impossible.

41. See Congressional Budget Office, Temporary Measures to Stimulate Employment, p. 37. 
jobs may be workers who would normally make $\$ 12,000$. To maximize family welfare, the optimum candidate for such a job may be the man or woman who has never earned more than $\$ 7,000$.

While wages in public-employment jobs average about $\$ 8,000$ a year, available evidence indicates that they vary with demographic characteristics in the same way that wages do in the private labor market: young people, members of minority groups, those with relatively little education, and females tend to occupy lower-paying jobs. ${ }^{42}$ Because of this correlation, it is difficult to draw inferences about alternatives available to participants on the basis of their personal characteristics alone. In other words, a former welfare recipient in a CETA job may be looking for something else just as intensely as is a college graduate.

Data on turnover of participants in EEA programs do not reveal systematic differences between demographic classes of workers that can be related to intensity of search for employment alternatives. ${ }^{43}$ Since the duration of subsidized jobs is rarely specified in advance, search is retarded by the possibility that such jobs will continue for extended periods, and, at least for EEA and in the early stages of CETA, by the emphasis placed on transition to regular government employment. ${ }^{44}$

Given this lack of information on wage effects, I concentrate here on the relation between unemployment rates and job allocation under CETA. In table 4, 1975 unemployment rates, the change in unemployment rates between 1974 and 1975, and CETA employment as a percent of labor force and of the change in unemployment are reported for workers in various demographic categories. Unemployment rates are reported for March 1975, approximately the midpoint of the period of public-employment expansion

42. Westat, Inc., Longitudinal Evaluation of the Public Employment Program and Validation of the PEP Data Bank: Final Report (Westat, 1975), p. 5-18.

43. Ibid., pp. 5-20 to 5-26. Young workers tended to terminate EEA employment quickly, but it is possible that the jobs provided members of this group were of particularly short duration.

44. Most public-service jobs are linked to entry positions on civil service employment ladders. Such a job gives its holder an edge in competition for regular slots as they open. Since steady salary growth and stability are still associated with such jobs in most areas, this edge is an important fringe benefit. In its study of high-impact demonstration public employment under EEA, the National Planning Association found that "cyclically unemployed" workers (those with a college education or who had experienced a wage cut in taking subsidized employment) earned relatively high wages while in subsidized jobs and nonetheless generally moved quickly back to unsubsidized jobs. But for most of this group, "unsubsidized" jobs were regular jobs in state and local government. See National Planning Association, Evaluation of the Economic Impact Project, vol. 1, p. 95. 
Table 4. Unemployment Rates and CETA Employment, by Demographic Category, 1974-75

\begin{tabular}{|c|c|c|c|c|}
\hline \multirow[b]{2}{*}{ Category } & \multirow[b]{2}{*}{$\begin{array}{c}\text { Unemployment } \\
\text { rate, } \\
\text { March } 1975 \\
\text { (percent) }\end{array}$} & \multirow{2}{*}{$\begin{array}{c}\text { Change in } \\
\text { unemployment } \\
\text { rate, } \\
\text { March } 1974 \text { to } \\
\text { March } 1975 \\
\text { (percentage } \\
\text { points) }\end{array}$} & \multicolumn{2}{|c|}{ CETA employment, March 1975} \\
\hline & & & $\begin{array}{l}\text { As a } \\
\text { percent of } \\
\text { labor force }\end{array}$ & $\begin{array}{c}\text { As a } \\
\text { percent of } \\
\text { change in } \\
\text { unemployment }\end{array}$ \\
\hline \multicolumn{5}{|l|}{ Age } \\
\hline $16-21$ & 19.8 & 6.4 & 0.42 & 6.5 \\
\hline $22-44$ & 8.9 & 4.4 & 0.33 & 7.1 \\
\hline $45-54$ & 6.0 & 2.9 & 0.12 & 4.3 \\
\hline 55 and over & 5.4 & 2.4 & 0.08 & 3.5 \\
\hline \multicolumn{5}{|l|}{ Sex } \\
\hline Male & 9.2 & 4.4 & 0.30 & 6.8 \\
\hline Female & 9.7 & 3.7 & 0.21 & 5.5 \\
\hline \multicolumn{5}{|l|}{ Race } \\
\hline White & 8.7 & 3.9 & 0.20 & 5.1 \\
\hline Nonwhite & 15.3 & 6.0 & 0.76 & 12.6 \\
\hline \multicolumn{5}{|l|}{ Education } \\
\hline 8 years or less & 12.0 & 5.9 & 0.20 & 3.6 \\
\hline 9-11 years & 15.5 & 5.9 & 0.28 & 4.9 \\
\hline 12 years & 9.4 & 4.6 & 0.29 & 6.1 \\
\hline More than 12 years & 5.2 & 2.1 & 0.25 & 11.4 \\
\hline
\end{tabular}

Sources: Unemployment and labor-force participation data, by age, race, and sex, are from Employment and Earnings, vo!. 20 (April 1974), and vol. 21 (April 1975). Unemployment and labor-force participation by education for March 1974 are from Beverly J. McEaddy, Educational Attainment of Workers, March 1974, Special Labor Force Report 175 (U.S. Bureau of Labor Statistics, 1975), table B. Data for 1975 were furnished by Division of Labor Force Studies, BLS. CETA employment rates were calculated from unpublished data supplied by U.S. Department of Labor, Employment and Training Administration. All unemployment figures are adjusted to include CETA jobs.

under CETA and the only month for which data on education of the labor force is available. As was the case for the SMSA data used in the regression reported earlier, the estimates for the unemployment rate in 1975 are adjusted to include CETA jobholders. The CETA rate is the ratio of CETA jobs filled as of March 1975 to the labor force in each category. ${ }^{45}$ It is the

45. The estimate is made by multiplying the ratio of the cumulative number of jobholders in each classification to total CETA employment through June 1975 by the number of CETA jobs filled at the end of March. This estimate is subject to two sources of error: (1) employment in March may not have had the same composition as that for earlier or later months; (2) the demographic data are cumulative and are biased toward overstatement of the CETA impact on high-turnover groups. 
demographic analogue of the rate employed earlier in this section for labormarket data.

No adjustment is made in the table to take account of changes in laborforce participation of the various demographic groups that occurred as the overall employment picture grew more dismal. Measured changes in unemployment rates are affected by those changes and may mask the distributional effect of the recession. However, I found no satisfactory way to eliminate the recession's discouraged-worker effect; the experimental adjustments that I tried had only negligible effects on the results shown in the table.

Several aspects of CETA job creation are apparent from the table. First, the program is small. For no category is the CETA rate substantial; it amounts to less than 1 percent for all categories and exceeds one-half of 1 percent only for nonwhites. Second, the incidence of CETA across categories has been broadly consistent with the desirable pattern relative to levels and changes in unemployment rates. Although women received proportionately fewer jobs than men, this is at least in part consistent with the greater increase in male joblessness, as is seen in the last column of the table. The underrepresentation of workers with little education is not consistent with appropriate targeting, in terms of the level or change of their unemployment. On the other hand, people with less than a high school education are heavily represented in CETA training programs. Public jobs need not be the appropriate policy for all workers during a recession.

Perhaps the most impressive characteristic of public-employment allocation under CETA is the substantial concentration on minority employment. Apparently, approximately one-eighth of all incremental unemployment occurring among nonwhites between March 1974 and March 1975 was absorbed by public jobs. This estimate is sensitive to errors in estimation of nonwhite unemployment rates, unknown induced changes in labor-force participation, and the assumption made about the effect of CETA jobs on measured unemployment. The impression, however, is robust with respect to all reasonable alternative assumptions: considering the size of the program, CETA has had a substantial effect on minority employment.

The same is true for workers with some college education. While the unemployment rate for this group in March 1975 was roughly half that of workers with only a high-school background (and had risen only half as much in the preceding year), its CETA rate was nearly as high. More than 
one-ninth of all recession unemployment among college-educated workers was absorbed by CETA.

The concentration on minority employment was greater under the early CETA-II program, as the result of its special targeting provisions. The concentration was eroded during the press for employment expansion that began in January of 1975. Table 5 reports the demographic composition of cumulative employment under EEA and the two CETA programs. Characteristics for CETA-II participants are separately reported for those employed in 1974 and those employed in 1975. Compared to EEA, the CETA-II program during the fall of 1974 reached proportionately more young, female, less well-educated, and nonwhite workers. But employment under CETA-VI proved to be similar in composition to employment under EEA. While CETA-II employment continued to be more focused on nonwhites and women than was the case for CETA-VI, the composition of employment shifted substantially in 1975 to better-educated workers. By June, overall employment in CETA looked much like employment under EEA. The type of targeting imposed by the allocation rules for CETA-II did initially concentrate jobs among a population different from that from which EEA employment was drawn, but apparently, as noted above, at the cost of delaying implementation.

The aggregated public-employment figures may disguise improvement over time in allocation within each category of jobs toward persons in severe need. Employment of former public-assistance recipients and disadvantaged persons is greater under CETA than was the case for EEA. Public-assistance recipients constituted approximately 15 percent of all CETA hires through June 1975, up from 12 percent of initial employees under EEA. About 46 percent of persons hired under CETA public-employment programs were classed as "economically disadvantaged" compared with less than 40 percent for EEA, although that may reflect the fact that the current criterion for "economically disadvantaged" is less rigorous than the one applied for EEA. ${ }^{46}$ For workers in newly formed households, the criterion is difficult to apply and the actual procedure followed at the local level is a matter of considerable uncertainty.

46. Currently, a person is deemed disadvantaged if he or she lives in a family that receives cash welfare payments or with income during the preceding year that is less than the Office of Management and Budget-Orshansky poverty thresholds. See Federal Register (March 19, 1974), p. 10376. For EEA, additional age, race, and educational qualifications were employed. See Manpower Report of the President, March 1973, p. 54. 
Table 5. Composition of Employment under Major Public-Employment Programs, by Demographic Category, Various Periods, 1971-75

Percent

\begin{tabular}{|c|c|c|c|c|c|}
\hline \multirow[b]{3}{*}{ Category } & \multirow{3}{*}{$\begin{array}{c}\text { Emer- } \\
\text { gency } \\
\text { Employ- } \\
\text { ment } \\
\text { Act to } \\
\text { June } 1972\end{array}$} & \multicolumn{4}{|c|}{ Comprehensive Training and Employment Act } \\
\hline & & \multicolumn{2}{|c|}{ Title II } & \multirow[b]{2}{*}{$\begin{array}{c}\text { Title VI, } \\
\text { January } \\
1975 \\
\text { to June } \\
1975\end{array}$} & \multirow{2}{*}{$\begin{array}{c}\text { Titles II } \\
\text { and VI, } \\
\text { July } \\
1974 \\
\text { to June } \\
1975\end{array}$} \\
\hline & & $\begin{array}{c}\text { July } \\
1974 \text { to } \\
\text { December } \\
1974\end{array}$ & $\begin{array}{c}\text { January } \\
1975 \\
\text { to June } \\
1975\end{array}$ & & \\
\hline \multicolumn{6}{|l|}{ Age } \\
\hline 21 or under & 20 & 22.9 & 24.1 & 21.4 & 22.7 \\
\hline $22-44$ & 65 & 62.6 & 63.0 & 64.8 & 63.7 \\
\hline $45-54$ & 10 & 9.4 & 8.0 & 9.1 & 8.7 \\
\hline 55 and over & 5 & 5.1 & 4.9 & 4.7 & 4.8 \\
\hline \multicolumn{6}{|l|}{ Sex } \\
\hline Male & 72 & 64.8 & 66.1 & 70.2 & 67.7 \\
\hline Female & 28 & 35.2 & 33.9 & 29.8 & 32.3 \\
\hline \multicolumn{6}{|l|}{ Race } \\
\hline White & 71 & 63.8 & 65.7 & 71.1 & 67.7 \\
\hline Nonwhite & 29 & 36.2 & 34.3 & 28.9 & 32.3 \\
\hline \multicolumn{6}{|l|}{ Education } \\
\hline 8 years or less) & & 9.4 & 9.3 & 8.4 & 8.9 \\
\hline 9-11 years & 21 & 20.1 & 17.5 & 18.2 & 18.3 \\
\hline 12 years & 43 & 44.1 & 41.9 & 43.7 & 43.1 \\
\hline More than 12 years & 31 & 26.4 & 31.2 & 29.6 & 29.7 \\
\hline
\end{tabular}

Souree: Unpublished program data furnished by U.S. Department of Labor, Employment and Training Administration. Figures are rounded.

Over 90 percent of EEA participants were reported as having been unemployed at the time of program entry. More than half of these people claimed to have been jobless for more than fifteen weeks at the time they were hired. Similar numbers are reported for CETA, although the data are somewhat distorted by the presence of some EEA carryovers, all of whom were "employed" prior to moving to CETA rolls. These numbers are highly suspect. A national survey of EEA participants conducted during 1972 and 1973 revealed that over a fifth of the employees interviewed had been employed on the day prior to accession to a subsidized job. ${ }^{47}$ If the figures on previous employment are this unreliable, there is no reason to

47. Westat, Inc., Longitudinal Evaluation of the Public Employment Program, pp. 4-5 to 4-7. The same survey confirmed the accuracy of the characteristics data employed earlier. 
believe those for duration. Since the basic procedures for hiring were no different for EEA and CETA, there is no reason to believe that the accuracy of the data has improved.

Perhaps, an unemployment criterion for admission is not critical to the effectiveness of public employment, since, when leaving for a subsidized job, a previously employed worker vacates one job which presumably can be filled by another person. But good political and economic reasons argue for retaining that criterion. To the public, it sounds right to limit such jobs to the jobless. Such a limitation also avoids creation of vacancies which, even though ultimately filled, will raise unemployment temporarily. A requirement that a public-service employee must have been unemployed serves to rotate the "job" of search for employment and the social burden of restraining inflation among a larger group of workers. To a modest extent, this criterion may improve the distribution of income resulting from the program. These factors suggest that the longer the duration of unemployment required as a condition of public employment the better. The cost of these improvements is that, as the duration requirement is lengthened, search costs for the employer multiply and speed of job creation declines.

Only 14 percent of unemployed enrollees in CETA report that they were receiving unemployment insurance benefits at the time of program entry. ${ }^{48}$ The low figure is a puzzle. During the first half of 1975, about two-thirds of all unemployment was insured in one form or another. Since there are few incentives for underreporting-receipt of benefits presumably confirms unemployment-perhaps new labor-force entrants are more extensively represented in CETA than the official data imply or the program has succeeded in picking exhaustees, workers formerly employed in uncovered jobs, or those jobless for only a very short period (though the last explanation is inconsistent with the long duration of unemployment reported by program jobholders).

\section{SUMMARY}

Among the metropolitan areas used for analysis here, CETA public employment was closely related to levels of unemployment rates but only weakly to cyclical increases in unemployment rates. Since the geographic

48. This number is derived from unpublished tabulations of CETA participant characteristics furnished by U.S. Department of Labor, Employment and Training Administration. 
dispersion of unemployment rates declines during economic recovery, all stimulative policies will reduce dispersion. Apparently, however, public employment performs better than the average in this respect.

Nor did I find direct evidence that public employment is concentrated on workers from disadvantaged households. While there is a high concentration among minority groups, there is an especially small participation of low-education groups. Survey data suggest that the degree to which such jobs go to persons who have suffered from extended joblessness is exaggerated. Under existing programs, program agents have little incentive to seek out such workers or to be concerned about the reliability of information that is collected on worker poverty or on employment status. Therefore, this result is probably not surprising. Few CETA jobholders report receiving unemployment insurance immediately prior to obtaining their CETA jobs. In general, there is no evidence to support the contention that the type of workers hired through public-employment programs means a reduction in payments of unemployment-insurance benefits or in other government transfers, or an increase in tax collections beyond that which occurs whenever employment expands.

\section{Conclusions for Improving Public Employment}

Since I have already summarized my findings on implementation, displacement, and targeting, my final remarks deal with improvements that might be incorporated into any future antirecessionary public-employment program.

The big virtues of existing public-employment procedures are speed and job impact. Reforms should be sought that improve the other qualities of the program while sacrificing as little of these virtues as possible. Five changes can be expected to improve the impact of the program:

First, add to the collection of rules for job allocation one specifically based on the excess of current unemployment rates above past averages for each labor market.

Second, augment the program with some type of countercyclical revenue sharing. Present procedures implicitly require local governments to cut taxes or reduce expenditures on regular functions in order to undertake the stabilization function appropriately borne by Washington. Increasing "equipment money" can speed implementation and reduce displacement 
Even with this added support, however, public employment cannot alleviate the "fiscal crisis" of the older central cities, and should not be used in an attempt to "save" New York or Detroit. There surely are better tools for implementing a public-policy goal of reversing the secular decline of the nation's central cities.

Third, limit jobholders in a countercyclical program to a fixed tenure. My preference is for a one-year tenure. This procedure has several advantages. First, it would place jobs under review for maintenance of effort on an annual basis rather than at initiation only. Second, fixed tenure would create incentives for public jobholders to continue search for regular employment alternatives. Third, fixed tenure would permit a countercyclical public-employment program to be closed within a year. It is essential that persons unable to find alternative employment after tenure as special public employees be given assistance in job search, training, and unemployment benefits as appropriate.

Fourth, maintain during recession the classroom and on-the-job training programs that are the normal activity of the local prime sponsors. The population served by these programs is more uniformly disadvantaged than is that served by public employment. Substituting countercyclical employment for these activities has adverse distributional consequences and should be avoided.

Fifth, remove the certification procedure for public-employment eligibility to a separate agency that has contact with the entire eligible group. The process of sifting applicants for those who are eligible takes time; and the more complicated the eligibility criteria applied, the longer the time involved. State employment services have the advantage of a more general perspective on the labor force, files of potential jobholders that could be rapidly scanned for the eligible, and superior information on duration of employment, and are the logical candidates for this function. 


\section{Comments and Discussion}

R. A. Gordon: Wiseman's evaluation of American experience with publicservice employment during the last five years is a welcome addition to a growing literature. It is carefully done; the relevant literature and data have been reviewed; on the whole, the important issues are covered; and the various topics considered are treated with analytical sophistication. The section on lags in the implementation of public-service employment programs is especially well done, and I found it very informative. In particular, I had not thought very much about the problems involved in closing out a program as unemployment falls.

Yet, I must confess to a certain disappointment when I had finished reading the paper. In much of it, Wiseman largely confines himself to reviewing and evaluating the work of others. Only in the last empirical section, on "targeting," does he introduce any significant amount of new data on his own. I am sorry that he did not choose to make use of other data that he has compiled that might have thrown additional light on a complex and controversial subject.

Wiseman considers public-service employment only in terms of its possible role in coping with a cyclical rise in unemployment. This emphasis leads him in his concluding recommendations to propose that public-service employment be limited to a fixed tenure that "would permit a countercyclical ... program to be closed within a year." Other types of manpower programs and unemployment benefits would have to take care of those who cannot find a job after their limited period of employment in the program.

As Wiseman recognizes, some economists have advocated a "two-tier" program, consisting of (1) a triggered, cyclical program such as he is concerned with, and (2) a permanent program to deal with the structurally disadvantaged. I should like to be on record as favoring such a two-tier 
program. A full consideration of the possible contributions that publicservice employment can make to reducing the average level of unemployment in the United States over a decade or more requires consideration of what it might contribute to the employment and training of the structurally underprivileged.

Now for a few comments on particular points in Wiseman's presentation. First, the author frequently refers to the goal of returning to a "normal" unemployment rate, and early in his paper he refers to "normal" or "fullemployment rates" as synonymous. It would be helpful to know what he means by "normal" or "full" employment in the latter half of the 1970s. Does he mean an overall unemployment rate in the range of 4 to 5 percent, with the implication that a public-service employment program, on whatever scale, is not to be reduced until the upper limit of this range is reached? If so, an opportunity to terminate or even reduce the present program is hardly likely for quite a while.

One of the most vigorously debated issues in the literature on publicservice employment concerns the amount of leakage-what Wiseman calls displacement. Here, Wiseman does an excellent and unusually thorough job in evaluating the main studies that have been made of this problem. He reaches rather negative conclusions that stress lack of reliable estimates of the displacement effect. If that is the case, how might we make more reliable estimates?

The section on targeting raises a range of questions. One has to do with the author's concern regarding the possible inflationary effects of an increase in the demand for labor through public-service employment. He assumes that the inflationary effect will be minimized if these jobs are distributed geographically in a way that emphasizes the change in local unemployment above prerecession levels. I think a good case can be made for using the level of unemployment as a primary criterion. I am not even convinced that changes in unemployment rates deserve to be treated as a separate, additional, criterion. In any event, the existing and any foreseeable public-service employment programs are too small to stir concern about significant inflationary effects.

The author provides a careful and very useful analysis of the distribution of public-service jobs by age, sex, race, and education. This analysis leads to a mixed set of conclusions: "While there is a high concentration among minority groups, there is an especially small participation of low-education groups" in public-employment programs. 
Wiseman concludes with a number of recommendations. I am afraid I have to disagree with two of them. First, as I have already indicated, I am not convinced that the geographical allocation of jobs should be geared to changes in unemployment, rather than just the level of unemployment. And, second, fixed and limited tenure of public-service jobs is much too harsh and inflexible a rule for my taste. This criticism brings me back to the point I have already made. We need a two-tier program that will take care of the structurally disadvantaged as well as those temporarily unemployed during a short recession.

But despite my criticisms on particular points, let me conclude by repeating that Wiseman has presented us with a probing and useful analysis of our recent experience with public-service employment.

James Tobin: I see three major sets of criteria against which public-service employment programs might be evaluated. First, they might be considered as distributive and allocative policies, with micro rather than macro implications. One question, from this perspective, is whether the programs improve equity in the distribution of income and of jobs. The distribution of employment and unemployment seems quite unfair to many citizens, and they might want to alter it regardless of macroeconomic consequences. Another question is the value of the social product from putting people to work on these programs-for example, beautifying New York City. A third aspect might reflect a moral preference for people working rather than receiving transfer payments without working. In considering the range of issues associated with public-service employment, some attention to these micro issues seems desirable; they are completely ignored in Wiseman's paper.

A second major set of criteria would view public-service employment as a measure of fiscal policy, stressing the size of its multiplier, its quantum of bang for a buck. Wiseman devotes considerable attention to this question; for example, the displacement issue that occupies much of the paper is purely a matter of the size of the multiplier. The multiplier can be viewed in terms of employment created either per dollar of government expenditure or per dollar of federal deficit. The latter is less interesting to me, but may be important, insofar as people worry about the deficit. But the whole question is overstressed. We do not lack fiscal and monetary policy instruments that will create public and private jobs. If public-service employment 
programs result in more jobs per dollar than tax cuts or monetary ease, the difference is only in the first round of the multiplier process and will survive only if other macro policies are accommodative.

The third set of criteria concerns the usefulness of public-service employment as a measure for improving the Phillips-curve tradeoff between inflation and unemployment and lowering the nonaccelerating-inflation rate of unemployment. To me, this is the most important issue from the point of view of macroeconomic policy; yet Wiseman gives it less attention than the multiplier issue, and sometimes does not clearly distinguish between the two.

There are several ways in which public-service employment might improve the tradeoff. One of these mechanisms hinges on the point made by George Perry that the rate of wage increase of individual workers influences economy-wide wage inflation with weights that are proportional to the shares of individual workers in the aggregate wage bill; thus, a given rate of wage inflation for low-wage workers has less aggregate effect than would the same rate for high-wage workers. On the other hand, individual workers are equal in the count of unemployment; one can infer that, in at least one dimension of our social-welfare function, unemployed people get equal weights rather than wage weights. By that standard, it becomes possible to increase welfare by concentrating employment gains on low-wage workers. Public-service employment programs could accomplish this in principle, whether they actually do or not. Of course, if the contribution of reducing unemployment to social welfare is merely a proxy for the associated increase in output-the Okun's law relationship between unemployment and output - then a redistribution of employment in favor of low-wage workers does not improve social welfare since, presumably, the increase in output is proportional to the wage of the employee and not merely to the count of heads.

Second, public-employment programs may improve the tradeoff by hiring people who are on relatively flat segments of their sectoral Phillips curves. Added employment for such groups would tighten the labor market less than would the same gain in employment achieved from the normal mixture of jobs associated with expansion of aggregate demand. There may be large differences in the slopes of sectoral Phillips curves at any overall unemployment rate. In practice, this consideration probably leads to the same focus on low-wage jobs and on unskilled workers as the first consideration. For example, when the job market for skilled prime-age males becomes tight, the teenage market may still be quite loose; and the mar- 
ginal tightening there from a given increase in employment would then be much smaller.

Wiseman's findings indicate that actual public-employment programs have not taken much advantage of this possibility of focusing employment on labor markets with flat Phillips curves. In evaluating that issue, Wiseman looks particularly at the excess of the unemployment rate in any city or for any group above its previous "prosperity" level; that assumes that those groups whose unemployment has increased the most during the recession are the ones that are on the flatter segments of the Phillips curve. I question that assumption, and would suggest that the recession level of unemployment might be a better gauge for that purpose than the increase. And, as Wiseman recognizes, the programs would get a better grade for allocating jobs among cities by the level criterion.

Still a third improvement in the tradeoff, which Wiseman mentions, relates to the possibility that workers in public-employment programs may be more active in seeking other jobs than would people employed elsewhere. If they are sufficiently active, they may be restraining wage inflation almost as much as if they were fully unemployed. This is likely to be true if the beneficiaries of public-service programs perceive their jobs as lower in wage and status and more transient than regular jobs. Presumably that is the point to Arthur Burns' proposal that employer-of-last-resort jobs pay wages below the current standard minimum wage and to Wiseman's proposal for limiting the tenure of public-employment jobs.

I have tried to sketch a simple algebraic framework for thinking about these matters. In this model, wage inflation is related both to vacancies and to unemployment, naturally with opposite signs. Normally, when additional jobs are created, vacancies also increase and hence it takes more than 100 newly created jobs (or job slots) to produce a net increase of 100 in actual employment (or filled jobs). The model (displayed on the next page) also includes the usual induced effect on the supply of labor, which I take to depend on the number of jobs, including vacancies as well as filled jobs.

In the model,

$$
\begin{aligned}
& U=\text { unemployment } \\
& S=\text { labor supply } \\
& E=\text { employment } \\
& J=\text { jobs } \\
& W=\text { wage-inflation rate } \\
& V=\text { vacancies }
\end{aligned}
$$




$$
\begin{aligned}
& U=S-E \\
& V=J-E \\
& W=\phi(V, U) \quad \phi_{V}>0, \phi_{U}<0
\end{aligned}
$$

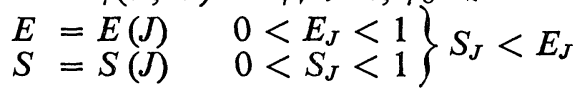

$$
\begin{aligned}
& \frac{\partial U}{\partial E}=\frac{S_{J}-E_{J}}{E_{J}} \quad \frac{\partial V}{\partial E}=\frac{1-E_{J}}{E_{J}} \\
& \frac{\partial W}{\partial E}=\phi_{V}\left(\frac{1-E_{J}}{E_{J}}\right)+\phi_{U}\left(\frac{S_{J}-E_{J}}{E_{J}}\right) \\
& x=\frac{\partial W / \partial E}{\partial U / \partial E}=\phi_{V}\left(\frac{1-E_{J}}{S_{J}-E_{J}}\right)+\phi_{U}<0 \\
& \frac{\partial x}{\partial E_{J}}=\phi_{V} \frac{1-S_{J}}{\left(S_{J}-E_{J}\right)^{2}}>0 \quad \frac{\partial x}{\partial S_{J}}=-\phi_{V} \frac{1}{\left(S_{J}-E_{J}\right)^{2}}<0 \quad \frac{\partial x}{\partial \phi_{U}}=1 .
\end{aligned}
$$

In the framework of this model, public-service employment can conceivably improve the tradeoff (lower the absolute value of $x$ ) in several ways. One would be by diminishing the number of extra vacancies that go along with additional jobs or additional employment (raising $E_{J}$ ). If vacancies rise to a lesser extent for a given amount of additional employment, then the economy would not experience so much additional wage pressure. The best program of all would find a way to fill existing vacancies with unemployed workers. Public-service employment programs can't be expected to do that, but they may be able to keep job creation geared closely to jobs filled without producing extra vacancies. They may also be associated with a particularly small induced labor-supply effect (that is, a low $S_{J}$ ) because of their selective and transient nature; some people who are out of the labor force might not be eligible for such jobs and others might not be attracted to them. Finally, by the right selective measures, the programs might conceivably improve the disciplining effect of unemployment on wage inflation (increasing the absolute value of $\phi_{U}$ ). Some of the characteristics of publicservice employment programs that might be desirable for improving the Phillips curve would be undesirable on the basis of other criteria. For example, transient jobs may not be jobs of high social productivity, may not build human capital or motivate careers. Similarly, the best techniques for minimizing wage inflation may not serve criteria of equity and need. Some of these considerations lead me to wonder whether a program that placed eligible workers into private or public jobs with a federal wage subsidy might not be a better device for balancing several objectives than are the public-service employment programs. 


\section{General Discussion}

A number of participants probed further into the problem of assessing the multiple objectives of public-employment programs as set forth by Wiseman and elaborated by Tobin. It was generally agreed that the success of antirecession policy could not be gauged solely by its effect on the measured unemployment rate. Arthur Okun pointed out that, if the nation wanted merely to reduce reported unemployment, there would be trivial (and actually perverse) ways to accomplish that aim-for example, requiring recipients of unemployment insurance not to seek work so that they would be counted as being out of the labor force rather than as unemployed. He felt, along with Tobin, that gains in real income and output were the main objectives. Robert J. Gordon noted, however, that the distribution of the real income lost during recession was a source of social concern; hence, measures that might share the burden more equitably would be attractive quite apart from their effects on total real income. Robert A. Gordon stressed that the number of people out of work against their will in and of itself detracted from his concept of social welfare. William Poole linked this consideration to the personal satisfactions that people get out of having jobs and contributing to the social product. $\mathrm{He}$ noted that this value of employment gets perverted in proposals to force people into unattractive "workfare" jobs, or work-conditioned income maintenance, as a way of getting them off welfare rolls.

Christopher Sims generalized the issues raised in this discussion; he pointed out that the welfare evaluation of unemployment depended upon the usual correlations of unemployment with other variables-the productivity of workers, their satisfaction with jobs, participation in the labor force, and the like. To the extent that these relations are altered by a particular kind of employment program, the social significance of unemployment is changed. For example, if in fact the programs that Wiseman evaluated were less effective in attracting people into the labor force than other kinds of employment were, this may be an advantage in holding down the unemployment number; but it may be a disadvantage in terms of effects on output and the efficiency of allocation. William Fellner inferred the need for an educational effort to persuade the public to pay less attention to the measured unemployment rate and more attention to the benefits and costs that various programs offer to nonworkers, whether they are categorized as unemployed or as out of the labor force. 
There was further discussion of the criteria by which jobs could be targeted to minimize inflationary impacts. Nobody contested Wiseman's judgment that the "normal" unemployment rate of a given geographical, occupational, or demographic labor market is one indicator of that market's ability to digest a relatively large increment of jobs in a noninflationary way. But James Tobin reiterated his warning against assuming that all labor markets had Phillips curves with the same slopes at their "normal" unemployment rates. Charles Holt shared R. A. Gordon's feeling that these targeting issues were not of great significance for small programs like the recent CETA efforts; but he judged that they could be critical in the context of larger, permanent structural programs of job creation. Michael Wachter interpreted the absence of sound criteria for targeting or triggering as a distinct general defect of countercyclical public-service programs. He was also concerned that job creation in the public sector might be especially inflationary because the state and local sector had been marked by such a strong spiral of wage inflation prior to the recession.

Wachter was also skeptical about the productivity of public-service jobs, in part because they were so temporary, and in part because they represented an inflow of low-skilled workers into a sector that has rather highskill job requirements. Edward Gramlich underlined the fact that the average education of state and local employees was far above that of workers in general; hence, Wiseman's finding that CETA misses undereducated workers should not be surprising. George Perry noted that idle capital in recession was concentrated in the private sector; he saw that as one reason to prefer the creation of private jobs whereby capital as well as labor would be put to work. Holt cautioned Wachter and others not to assume that short-term jobs were low-productivity jobs relative to the wages they paid; he stressed that job tenure throughout the economy averages only two years roughly. Robert Solow suggested that, if state and local administrators are given an incentive to hire lower-skilled workers, they are likely to make adjustments in that direction. Wiseman supported that view, judging that some of the educational standards applied in regular public employment were unnecessary and that these might be bent in response to federal programs that gave preference to less-educated workers.

These issues led to a general discussion of the displacement effect. Martin Feldstein was concerned about public-service jobs displacing private employment as well as other jobs in the public sector. He inferred some substitution of public for private jobs from Wiseman's findings that only a small percentage of public-service jobholders had been receiving unemploy- 
ment insurance at the time of starting the program job. Although granting that a vacated private job could be filled by somebody else, Feldstein noted that, even in recession, private vacancies are not filled instantaneously; in effect, the $E_{J}$ parameter in Tobin's model is a source of leakage. Holt stressed that the funds freed by the so-called displacement effect may still exert a substantial stimulus by leading to lower taxes and hence increased private spending or more state and local spending on other programs. Unlike Feldstein, he did not interpret the low figure on unemploymentinsurance beneficiaries at the time of starting public-service jobs as a symptom of either high displacement or poor implementation. Given the lag between hiring and employment, a person who starts his public-service job may be leaving a strictly fill-in private job that he landed after he applied for the public-service job.

Gramlich commented that, the higher the displacement rate, the more the impact of public employment approaches that of general revenue sharing, and the stronger the case for countercyclical general grants to state and local governments. Such grants would enable them to maintain their employment in ways that they find most efficient and to avoid cyclically perverse personnel policies. Wachter, on the other hand, saw a high longrun displacement rate as a safety valve on the program, ensuring that it really became the equivalent of general revenue sharing (rather than distorting the composition of state and local employment) when prosperity was restored.

A number of participants commented on Tobin's tentative endorsement of a wage subsidy applicable to private or public employment. Feldstein was a strong supporter of this approach; he reminded the group that, for private goods as well as for public ones, the social opportunity cost of labor is far below the going wage when unemployment is high. The ideal countercyclical job-creating program should not discriminate between public and private employment, he concluded. Tobin amplified his original comment by sketching a voucher proposal that had been advanced by Guy Orcutt. According to that plan, vouchers would be given to individuals who meet certain eligibility requirements that establish their difficulties in the labor market. The voucher could be transferred either to a public or a private employer and would be cashable so that the federal government paid part of the wages of the worker. R. J. Gordon was attracted in principle by such a program but wondered how the eligibility standards might be determined and how the balance could be struck to set subsidies high enough to be attractive and yet low enough to be efficient. In response to a question from 
Sims on how subsidy programs might wind down, Tobin stated that the voucher program would not be purely countercyclical but would respond countercyclically since the eligible population would wind itself down in a prosperous economy. Perry wondered whether that might not introduce a procyclical inflationary effect, since the wage costs borne by the employer would be reduced substantially by the subsidy during recession but only a little in times of high employment.

Wachter agreed that the subsidization of private jobs deserved more exploration, but thought that manpower training also merited greater emphasis. He felt that training programs had not received a fair trial. Fellner also supported training programs, particularly-in line with R. A. Gordon's judgment-as a way to deal jointly with structural and cyclical employment problems. Fellner stated the criterion that, any time it is possible to build, through training programs, human capital with social value that exceeds the cost of such programs over and above the cost of income maintenance, such training is clearly advantageous.

Barry Bosworth offered several arguments in favor of some reliance on countercyclical public-service employment. He considered it likely that more net new jobs would be created by public-service employment than by subsidies to private employers, which might, in part, merely defray some private labor costs. More generally, he felt that training and private subsidies might be complements to public-service employment, rather than substitutes for it. Job experience and habit formation, which are important in most training efforts, might be developed effectively by public-service jobs. Moreover, whenever mistakes were made in stabilization policy that brought the unemployment rate far above levels justified on anti-inflationary grounds, he felt that the real choices were between income maintenance and public-service jobs. Bosworth was impressed by Wiseman's finding that the program jobs were productive; they also seemed to contribute to worker satisfaction. He thought the programs were superior to extended unemployment-insurance benefits and to welfare payments, and could be made even more effective with the administrative reforms that were recommended in the paper. Wiseman supported Bosworth's view that the CETA experience had refuted the "leaf-raking" concern. He expressed his own reservations about the likely response of the private sector to a countercyclical offer of job subsidies. Moreover, he doubted that the marginal product of employees in the public sector is much lower than that which would be attained in the private sector. 